Research, part of a Special Feature on Traditional Ecological Knowledge and Global Environmental Change

\title{
Biocultural Refugia: Combating the Erosion of Diversity in Landscapes of Food Production
}

\author{
$\underline{S t e p h a n ~ B a r t h e l ~}^{1,2}$, Carole L. Crumley ${ }^{1,3,4}$ and Uno Svedin $^{l}$
}

\begin{abstract}
There is urgent need to both reduce the rate of biodiversity loss caused by industrialized agriculture and feed more people. The aim of this paper is to highlight the role of places that harbor traditional ecological knowledge, artifacts, and methods when preserving biodiversity and ecosystem services in landscapes of food production. We use three examples in Europe of biocultural refugia, defined as the physical places that not only shelter farm biodiversity, but also carry knowledge and experiences about practical management of how to produce food while stewarding biodiversity and ecosystem services. Memory carriers include genotypes, landscape features, oral, and artistic traditions and self-organized systems of rules, and as such reflect a diverse portfolio of practices on how to deal with unpredictable change. We find that the rich biodiversity of many regionally distinct cultural landscapes has been maintained through different smallholder practices developed in relation to local environmental fluctuations and carried within biocultural refugia for as long as millennia. Places that transmit traditional ecological knowledge and practices hold important lessons for policy makers since they may provide genetic and cultural reservoirs - refugia — for the wide array of species that have co-evolved with humans in Europe for more than 6000 thousand yrs. Biodiversity restoration projects in domesticated landscapes can employ the biophysical elements and cultural practices embedded in biocultural refugia to create locally adapted small-scale mosaics of habitats that allow species to flourish and adapt to change. We conclude that such insights must be included in discussions of land-sparing vs. land-sharing when producing more food while combating loss of biodiversity. We found the latter strategy rational in domesticated landscapes with a long history of agriculture.
\end{abstract}

Key Words: agriculture; biocultural refugia; diversity; ecosystem restoration; resilience; small holders; stewardship,

\section{INTRODUCTION}

In the very near future our planet will need to feed nine billion human beings, yet the accelerating rate of biodiversity loss in landscapes of food-feed-fiber-fuel production threatens to erode the capacity of such landscapes to generate vital ecosystem services (Ferrier et al. 2004, Foley et al. 2005, Chappell and LaValle 2009, Phalan et al. 2011, Godfray 2011). The Convention on Biological Diversity calls for reducing modern agriculture's pressure on biodiversity (Perrings et al. 2010); an example of societal response is the storage of plant genetic material at the Svalberg Global Seed Vault in Norway.

As worthy as such efforts are, we present a case for extending them to the promotion of place-based knowledge and methods for cultivating plants and animals that have been developed by people living in a particular biome and cultural context. Our discussion employs the discourse of social memory and focuses on the carriers by which knowledge, experience, and practice of managing a local ecosystem and its services are captured, stored, revived, and transmitted through time (Barthel et al. 2010).

We call the landscapes that harbor such social memory biocultural refugia (Barthel et al. 2013a). Paleobiology customarily defines a refugium as a geographical area of relative ecological stability that enables long-term survival of a defined biota during periods of glaciation, and from which new populations can migrate back to former colonized areas during warmer periods (and vice versa) (Haffer 1982, Tallis 1991). Biocultural refugia do not simply shelter a defined biota; they also carry knowledge about the practical management of food production while maintaining biodiversity and ecosystem services (cf. Barthel et al. 2013a).

We have argued elsewhere (Barthel et al. 2013a) that the varying historical and geographical conditions for the cultivation of species require strategies to safeguard placebased knowledge and practices that relate to these conditions (see also Boillat and Berkes 2013). Traditional ecological knowledge (TEK), often integrated into such place-based knowledge (Olsson and Folke 2001, McKenna et al. 2008), is of importance to the sustainable stewardship of any cultural landscape: it contains the cumulative and evolving body of knowledge, practices, and beliefs held by communities about their relations with the ecosystems in which they are embedded (cf. Gadgil et al. 1993, cf. Berkes et al. 2000, cf. GómezBaggethun 2012). The literature on TEK teaches us that it is never static. Instead, TEK is responsive to global changes and pressures (Gomez-Bagethun et al. 2012, Gomez-Bagethun and Reyes-Garcia 2013, Reyes-Garcia et al. 2013), so that it becomes a sort of hybrid dynamic knowledge (GómezBaggethun et al. 2013). We make the case here that TEK

\footnotetext{
${ }^{1}$ Stockholm Resilience Centre, Stockholm University, Sweden, ${ }^{2}$ Department of History, Stockholm University, Stockholm, Sweden, ${ }^{3}$ Department of Archaeology and Ancient History, Uppsala University, Uppsala, Sweden, ${ }^{4}$ Swedish Biodiversity Centre, Swedish University of Agricultural Sciences (SLU), Uppsala, Sweden
} 
cannot endure if its biocultural contexts of transmission (Nazarea 2006, Davidson-Hunt et al. 2013) are transformed or streamlined by global standards and institutions (Barthel et al., 2013a; Oteros-Rozas et al. 2013, Turner and Spalding 2013). We shall show how biocultural refugia carry TEK, biodiversity, and ecosystem services, and discuss the role of biocultural refugia in building resilience in historical landscapes of food production.

Ecologists agree that unless sustainability strategies are implemented, efforts to increase food production will lead to catastrophic loss of biodiversity (Godfray 2011, Phalan et al. 2011, Perfecto and Vandermeer 2010). They do not agree on which strategies to implement to meet the dual challenges of increased food production and maintaining biodiversity (Green et al. 2005). Ecologists with a cultural orientation often argue for "land sharing," the spatial integration of food production and biodiversity preservation. Some ecologists argue for "land sparing," the spatial separation of biodiversity conservation from food production (Balmford et al. 2005, Phalan et al. 2011). Each approach has its drawbacks. The land sparing concept can be misused to defend monoculture and the intensive use of pesticides and other agrichemicals (Emsley 2001, Avery 2007, Godfray 2011). Taken to an extreme, it can be interpreted as legitimizing the land- and water-grabbing that threaten family farms in the global south (Rulli et al. 2013). The land sharing approach does not make sense in places that lack a deep history of agriculture or in places where agricultural practices are not adapted to their ecological or cultural context. On the other hand, land sparing makes little sense in landscapes with a deep history of agriculture: species and practices have been adapted to those places through millennia of domestication (Rindos 1980, Maffi and Woodley 2010). The ubiquitous industrialization of agriculture is rapidly eroding such practices and the biodiversity associated with them, treating them as "obsolete." Traditional practices, along with their stewardship of interlinked social-ecological systems, are discarded in a kind of ongoing generational amnesia (Leopold 1949, Kahn 2002, Emanuelsson 2010).

Agricultural practices associated with current forms of industrialization lead to an extraordinary rate of biodiversity loss (Vitousek et al. 1997, Tscharntke et al. 2005, Rockström et al. 2009, Phalan et al. 2011). Of all remaining terrestrial species, an estimated $43 \%$ are connected to landscapes presently or recently producing food-feed-fiber-fuel (Ferrier et al. 2004, Chappell and LaValle 2009). Many of those species are now threatened by the imposition of efficiency-driven contemporary agriculture and the accompanying loss of longestablished locally evolved practices. Entire habitats, and wild species associated with them, as well as domesticated landraces developed through millennia of deliberate breeding, have been lost or are on extinction trajectories (Benton et al. 2003, Negri 2005, Emanuelsson 2010). It is now well established that the current loss of agri-biodiversity also directly and indirectly erodes fundamental ecosystem services underlying the resilience of production, such as soil fertility, pollination, and natural pest control (Kearns et al. 1998, Gurr et al. 2003, Tscharntke et al. 2005, Steffan-Dewenter et al. 2005, Foley et al. 2005, Biesmeijer et al. 2006, Klein et al. 2007, Ingram et al. 2008).

We describe some of the challenges involved in the production of more food while halting the loss of biodiversity. We then discuss how biocultural refugia transmit TEK between people and across cohorts and how they are linked to a sustainable use of historical landscapes of food production. Next, we explore the origins of biocultural refugia and how they contribute to resilience; we provide some examples to illustrate key attributes of biocultural refugia. Finally, we look at the implications of our concept of biocultural refugia for food sovereignty, biodiversity, and ecosystem restoration. Our argument is supported by European examples, but it applies to any region with a long history of agriculture and mixed cultivation.

\section{Drivers of erosion of TEK, food sovereignty, and biodiversity in agricultural landscapes}

Chemical-intensive industrialized monoculture of vast areas in agricultural heartlands is the main driver of biodiversity loss in landscapes of food production (Tscharntke et al. 2005, Chappell and LaValle 2009). Species loss often follows the abandonment of land that is marginally productive on account of steep terrain, poor soil, or other factors making farming difficult (Queiroz 2013). It would seem that leaving such marginal lands fallow would increase biodiversity, but extensive research in varied agricultural landscapes has found that such landscapes as meadows grazed by cows or used for making hay often harbor significantly higher levels of plant biodiversity than those abandoned to bush-encroachment: the succession following abandonment of farmland leads to local extinction of many species that have adapted to and are often promoted in traditional agricultural practices (Lindborg and Ericksson 2004, Ericksson et al. 2002, Nabhan 1997, 2008, Emanuelsson 2010, Báldi et al. 2012). Many species and genotypes in the cultural landscapes of Europe are, in fact, emergent properties of millennia-long coevolution, where humans and domesticated species were dependent on each other for survival in a dialectical relationship (Rindos 1980, 1984, 1986, Groonenborn 2009). Past conditions and practices have interacted with local biota, shaping social-ecological systems in landscapes of food production and beyond (Rindos 1980, Crumley 1994, Nabhan 1997, Barthel et al. 2005, Kaplan et al. 2009, Emanuelsson 2010).

The chief driver of the current form of industrialization has been to increase profit; its context has been population growth, changing diet, economic globalization, and climate change (Steffen et al. 2007, McMichael 2009, IAASTD 2009, Svedin 
2012). Industrialized agriculture is characterized by uniform practices over broad spatial scales and the intensive use of nonrenewable resources such as fossil fuels, fossil water, as well as artificial fertilizers, pesticides, and herbicides. Relatively few varieties are grown, and more and more of these have been genetically modified (Horlings and Marsden 2011). Additional gains in crop yield per land area may keep up with population growth, rising standards of living, and shifting eating habits. The prevailing global model, driven by the quest for a special form of economic growth and profit, increases efficiency by cutting the ratio of cost of labor to crop yields. Practices destructive of biodiversity, such as land grabbing and chemically intensive monoculture, typically accompany this process unless policy interventions are designed and applied. Farmers can fall into a kind of efficiency trap (Scheffer and Westley 2007, Strumsky et al. 2010): energy costs escalate and marginal returns from fertilizers and pesticides diminish, while associated environmental problems such as greenhouse gas emissions, water degradation, topsoil loss, and loss of biodiversity accumulate. From a social sustainability perspective these destructive practices lead to a spatial disconnect between consumers and food production. An uneven distribution of food (Patel 2008) causes problems such as an increase in the number of undernourished children in many countries (FAO 2006, 2008, IAASTD 2009).

Resolving the problems inherent in the current system will require a variety of approaches (IAASTD 2009, Cordell et al. 2009, De Schutter and Vanloqueren 2011, Horlings and Marsden 2011, Fraser and Rimas 2010, Lin et al. 2011). More thorough analysis and critique of the dynamics of the global food system are needed (McMichael 2009, 2011, Norgaard 2010, Harvey 2010). Alternatives to an exclusive and inadequate focus on increasing crop yields must be developed. A truly sustainable agriculture entails resilience building at local and regional scales (Ruiz-Mallén and Corbera 2013), including the capacity to design varied and locally relevant means of production, with a distinct focus on access to land and resources, sometimes referred to as food sovereignty, to support biodiversity and grow healthy food (Watts and Bohle 1993, Sen 1994, Ericksen 2008, Perfecto and Vandermeer 2010, Fraser and Rimas 2010, McMichael 2011). Our focus on biocultural refugia follows from these concerns.

A complex adaptive systems approach teaches us that understanding the evolutionary past of a domesticated landscape is essential when navigating its future (Crumley 2000, Levin 1998, Lansing 2003, Scarborough 2008). Biocultural refugia are often products of many generations of traditional small-holding farming practices; we argue, therefore, that the protection and promotion of smallholders is a vital component of any solution (Netting 1993, Pretty et al. 2006, Petrini 2007, Pretty et al. 2006, Frison et al. 2006, De Schutter 2010, Perfecto and Vandermeer 2010, Horlings and Marsden 2011). Smallholders are rural cultivators practicing diversified agriculture on relatively small, often very productive farms. There is mounting evidence (Netting 1993) that many smallholders using agro-ecological practices produce a favorable ratio of energy return on investment, as measured in kilocalories; their practices are often more climate-smart than those of "modern" industrial agriculture; and productivity per unit of land is commonly inversely related to farm size (Netting 1993, Lin et al. 2011, IAASTD 2009). Smallholders using agro-ecological practices could increase food production globally to meet rising needs while promoting food sovereignty regionally, with substantially less erosion of biodiversity (Sen 1994, Rosset 1999, Pretty et al. 2006, Perfecto and Vandermeer 2010, Evans 2009, De Schutter 2010, Horlings and Marsden 2011). Because smallholder systems require more labor than highly mechanized monocultures, they could increase employment in rural areas that serve emerging markets for locally-grown food, 'slow food' and organic food (DeLind 2002, Friel et al. 2007, Petrini 2007, Pelletier et al. 2008, Steel 2010, Fraser and Rimas 2010, McMichael 2011). The biodiversity that smallholders have always supported comes at no additional cost (Dahlström et al. 2013, Mikulcak et al. 2013).

\section{BIOCULTURAL REFUGIA AS CARRIERS OF TEK AND PRACTICAL SKILLS}

The degradation of biodiversity in domesticated landscapes has led to the preservation of seeds in facilities such as the Svalbard Global Seed Vault in Norway and the Vavilov Centre in Russia. As important as the preservation of genetic material may be, it is far from sufficient. TEK of how to raise particular plants co-emerged with the evolution of agro-biodiversity in particular geographical areas (Dahlberg 1993, Almekinders and Elings 2001) and is tightly linked to distinct combinations of species and varieties developed through long-term tinkering with environmental dynamics and cultivation practices (Altieri et al.1987, Jarvis and Hodgin 1999, Almekinders and Elings 2001, Gómez-Baggethun et al. 2010, Maffi and Woodley 2010, Siebert 2011). Loss of that TEK is as crucial as loss of species and varieties.

We cannot know exactly when and how TEK of the deep past survived and how successful traditional agricultural strategies were passed on, but the study of more contemporary social or collective memory teaches us that collective memory is maintained through social interaction in families, communities, settlements, and professional groups, and in religious practice (Halbwachs 1925, 1952, Connerton 1989, Nazarea 1998, Climo and Catell 2002, Misztal 2003). Agricultural families and communities have probably managed transmission of TEK in a number of ways. Songs, aphorisms, and poems are passed from one generation to the next; visual and other mnemonic cues are left in landscapes, monuments, and objects; the embodiment of everyday practice is taught through dance or the cadence of work; every written record is a "message in a bottle" from the past (Barthel et al. 
$2013 a$ ). At the same time, some social networks of information and knowledge systems become dominant (Castell 2009), which is why memory carriers (Table 1) of place-based knowledge and experiences are often intentionally transformed or erased (Turner and Spalding 2013). Powerful social networks may impose institutions, standards, or tools that do not fit local histories and conditions. Language, religion, habits, or livelihood of a target population may be suppressed. Memory carriers of TEK can also dissolve when people move from the country to the city (Barthel et al. 2013b) or if new markets emerge (Reyes-Garcia et al. 2013). Among the most powerful erasers of memory carriers is the passage of time: useful knowledge must be packaged for transmission to the future (Barthel et al. 2013a).

Table 1. Memory carriers of traditional ecological knowledge (TEK) and agricultural practices. (Modified after Barthel et al. 2013a).

\begin{tabular}{ll}
\hline \hline $\begin{array}{l}\text { Memory carriers of agricultural } \\
\text { practices and TEK }\end{array}$ & Examples \\
\hline Embodied Habits & $\begin{array}{l}\text { Communal rituals/ceremonies, } \\
\text { fertilization, pruning, water/ } \\
\text { snow sequestration, seed } \\
\text { selection/exchange } \\
\text { Narratives, teachings, proverbs, } \\
\text { songs, dances }\end{array}$ \\
Oral and Artistic Traditions & $\begin{array}{l}\text { Protection of various } \\
\text { organisms, taboos, norms of } \\
\text { social conduct, commons, } \\
\text { property rights }\end{array}$ \\
& $\begin{array}{l}\text { DNA in organisms, soil, } \\
\text { terrain, tools, artefacts, } \\
\text { landscape features, and written } \\
\text { Physical Things }\end{array}$ \\
& $\begin{array}{l}\text { accounts. } \\
\text { (Media, like TV and internet, } \\
\text { books and magazines, } \\
\text { regulations and laws, social } \\
\text { networks that include powerful } \\
\text { people) }\end{array}$ \\
\hline
\end{tabular}

Memory carriers of TEK evolve and tend to stabilize to a degree when sustained social engagement results in a shared history (Wenger 1998, Barthel et al. 2010). Memory carriers can be immaterial, like meanings and ideas, and physical, things like artifacts, landraces, and landscape features. They continue to transmit TEK long after the farmers who created them are gone (Table 1). In traditional agriculture, for instance, farmers save the best seeds from the harvest to plant for the next crop (Steinberg 2001). Over the millennia this practice develops locally adapted varieties of crops, landraces, and landscape features (Fraser and Rimas 2010) which serve as memory carriers for future generations of farmers. Rituals, oral traditions, written accounts, and self-organized systems of rules are also memory carriers (Hanna et al. 1996, Alcorn and Toledo 1998, Berkes and Folke 1998, Berkes et al. 2003, Barthel et al. 2010, Barthel et al. 2013a, Davidson-Hunt et al. 2013). The different types of memory carriers are interrelated, and they constantly evolve as they are shaped by social participation and by a changing environment (Wenger 1998, Scott 1998, Boillat and Berkes 2013). Just as any farmer's knowledge is in constant flux, memory carriers are emergent structures; they persist because they are both perturbable and resilient; they are continually revived through the incorporation of novel experiences (Barthel et al. 2010).

Biocultural refugia harbor memory carriers that enhance farm biodiversity (Barthel et al. 2013a) and contribute to resilience by helping to renew and reorganize the capacity of landscapes of food production to generate ecosystem services (cf. GomezBagethun et al. 2012), as when norms protect providers of natural pest regulation or pollination (Andersson et al. 2007, Tengö and Belfrage 2004). A biocultural refugium is like a library: employees and patrons come and go, buildings are renovated and extended, and books containing TEK are edited, added, or taken off the shelf. Landscapes, agricultural technologies, property rights regulations, and communitybased resource management practices: all are in the library (Barthel et al. 2010). Biocultural refugia can be viewed as 'pockets' of social-ecological memory (Barthel et al. 2010) in rural landscapes, offering access to hard-won TEK of food production using diversity as an overarching strategy (Boillat and Berkes 2013). Biocultural refugia - widely varied, placespecific, ever-evolving — produce and protect interlinked biological and cultural diversity, but TEK is being challenged and modified world-wide (Gomez-Baggethun et al. 2013). Just as a library can be torn down or transformed to other uses, biocultural refugia can be dominated or even swiftly wiped out, as is occurring now on a grand scale in 'land-grabbing' processes (Rulli et al. 2013). TEK is highly adaptive and flexible (Gomez-Baggethun et al. 2010, Gómez-Baggethun and Reyes-García 2013, Gomez-Baggethun et al. 2013), but no knowledge system is sustainable without its mnemonic carriers: without libraries, books and their contents are forgotten. Any TEK will fade away without its memory carriers; social memory would have nothing on which to work if the carriers of practical knowledge and place-specific experiences dissolve. The concept of biocultural refugia illuminates how TEK is transmitted, and points to the connections among physical landscapes, human actions, and ecological processes, and to the feedback loops that guide people in the management of agro-ecosystems.

Below we provide examples of biocultural refugia from varying geographical and institutional contexts in Europe and on different spatial scales, where memory carriers of placebased knowledge promote biodiversity in landscapes where food is produced. 


\section{Origins of biocultural refugia in Europe}

The industrialization of agriculture became widespread in Europe in the nineteenth century and accelerated after World War II. Before industrialization, landscapes created by the backbreaking labor of smallholders (Netting 1993) tended to maintain soil nutrients and were relatively rich in habitats, species, and genotypes (Benton et al. 2003, Eriksson et al. 2002, Lindborg and Eriksson 2004, Negri 2005, Fraser and Rimas 2010). Industrialized landscapes, on the other hand, have destroyed biodiversity (Emanuelsson 2010). Different stages of succession and dynamic landscape mosaics provided terrestrial and aquatic habitat for a vast array of domesticated and nondomesticated species (Bengtsson et al. 2003, 2005, Emanuelsson 2010). The development of the strategies and the capture and storage of experience of various selective pressures took place across thousands of years in Europe and across the world.

Biocultural refugia fit into the continuity of human/nature interrelationships that predate even the prehistoric spread of agriculture into Europe. Around eight thousand years ago, plants and animals that had been domesticated in various regions of Southwest Asia - Turkey, Iran, Iraq, and the eastern Mediterranean - began to spread to Europe along two major routes (Kaplan et al. 2009, Gronnenborn 2009). One followed the Danube River west from its delta in the Black Sea into the heart of temperate Europe: France, Germany, and Scandinavia. The other followed the Mediterranean littoral west into North Africa, Greece, Italy, southern France, and Spain (Gronenborn 2009). A remarkable suite of plants and animals arrived in Europe during the earliest farming period, an era called the Neolithic ("New Stone Age"), which ended about $6000 \mathrm{BP}$ when agriculture was in place throughout Europe (Gronenborn 2009). The heartiest of these domesticated species adapted over millennia to the new local habitats, under selective pressure from both increasingly proficient farmers and a capricious climate. Recent episodes of unseasonable weather make it easier for us to understand the hardships and potential disaster faced by ancient farmers: because there were no adequate means of transport to bring relief, a region's failed harvests in a ruinous year meant starvation. In fact, food supplies are not usually destabilized by sustained periods of intense cold or heat, or too much or too little rain: it is instead the variability of weather, epidemics, blights, and other factors which makes it impossible to plan for the next season with any assurance of success. The remedy for such climatic variability is diversity of species, knowledge, and practice (Crumley 2000, Boillat and Berkes 2013). Diversity in agriculture in Europe evolved in the course of coping with erratic environmental fluctuations and abrupt climatic shifts (Barthel et al. 2013a); accumulated experience of and responses to such changes are stored in living biota and in technologies such as ponds, terraces, and gardens (Widgren 2007).

\section{Examples of biocultural refugia}

Reservoirs of thousands of years of experience, historic agricultural landscapes in Europe often persist outside of industrialized agricultural heartlands, in steep terrain and in parts of Eastern Europe (Netting 1993, Beaufoy et al. 1994, Negri 2003, Emanuelsson 2010). These biocultural refugia have unique histories and co-evolving components of biocultural diversity (Jarvis and Hodgkin 1999, Eyzaguirre and Linares 2004). Biosphere Reserves are often biocultural refugia (Gomez- Baggethun et al. 2010). For example, Las Dehesas de Sierra Morena in southern Spain, though densely populated, supports high levels of biodiversity (Joffre et al. 1988). The small-holder systems of the ancient dehesas feature a mix of livestock, including hardy regional landraces of pigs, the cultivation of holm oaks, crops with long rotations, closed nutrient cycles, and no inputs of external fodder, fertilizers, or agrichemicals. As a result, the dehesa is a landscape of oaks surrounded by pasture, meadows, and scrub, rich in habitats, species, and genotypes (Joffre et al. 1988, Moreno and Pulido 2008, Oteros-Rozas et al. 2013). TEK is carried by physical features of the landscape such as oaks and meadows, by immaterial systems of property rights and protective institutions linked to those systems, and by social carriers such as methods of producing high-quality ham or wine corks, songs, and stories.

Protected areas are not the only biocultural refugia. Traditional ethical mores and agricultural practices persist in many villages in Croatia, for example. The family farmers of Štitar, Croatia, are close to the ideal of the European Union's Common Agricultural Policy (CAP) of socially sustainable farmers: competitive, diversified stewards of the environment. They offer a vision of a future combining high production levels and enhanced biodiversity. These family farms have survived over the years, transmitting experience from generation to generation, despite a turbulent history of despotic regimes, wars, and economic policies that do not favor small farmers. As Croatia prepared for a mid-2013 entry into the European Union, a year-long study of "smallholder" family farms was undertaken in Štitar, which is located in the Slavonia region in eastern Croatia (Dominkovic 2007). Policy makers and the general public often think of smallholders as backward, unproductive, inefficient, and resistant to change; Dominkovic's painstaking research dismantles this stereotype. Štitar's well-defined household hierarchies and the managerial skills of household heads contribute to farm families' long-term resilience. These farmers are market oriented and subsistence focused, diversify both plant production and animal husbandry, and invest more labor hours. As a result, their production costs are lower, they achieve higher output per land unit than industrialized farms, and they maintain a mosaic landscape that holds a diversity of habitats and high levels of species richness. The findings in Štitar support earlier research that traditional ecological 
knowledge can be combined with competitiveness in a market economy (Reyes-García et al. 2007, Gomez-Baggethun et al. 2013).

Romania is home to biocultural refugia with high levels of farm biodiversity and ecologically connected mosaic landscapes that continue to be shaped by traditional smallholder practices (Dahlström et al. 2013, Mikulcak et al. 2013). Two such places are Botiza and Surdesti in the Maramures region of Northern Carpathians. Seasonal rituals such as spring raking, haymaking, sheep grazing, burning, and bush clearing and artifacts associated with those rituals such as scythes, hayracks, and small barns for hay drying continue to function as carriers of TEK. Traditional practices have persisted in spite of communist-era collectivization, which finally ended along with the Ceausescu regime (1967-1989); these practices are more effective at ecological conservation than efforts to protect the same species in Sweden (Dahlström et al. 2013). Unfortunately, the imposition of the CAP in Romania is putting these biocultural refugia under severe pressure (Mikulcak et al. 2013).

\section{BIOCULTURAL REFUGIA AND RESILIENCE}

The diversity of continental landforms provides refugia for flora and fauna during climate change. In geologic history, small areas that were not fully glaciated, such as mountain ranges or mountainous coastlines, served as important refugia, since biota could "wander" vertically or laterally in response to climatic changes (Tribsch and Schönwetter 2003). As "green islands" or corridors in oceans of ice, refugia enabled flora and fauna to survive until the ice retreated and they could recolonize newly available habitats. Refugia function as genetic reservoirs by providing habitats for the survival of populations during both slow and abrupt environmental changes, such as glaciations, changing sea-levels or volcanic eruptions.

The same logic pertains to human-induced ecological disturbances. In Puerto Rico, the rain forests had been cleared for intensive agriculture, except for some small pockets at high elevations. As urbanization led people to abandon the countryside, rain forest species migrated from the mountain refugia and recovered large areas of the island. Such biotic spatial dynamics have been called the "ecological memory" of landscapes (Bengtsson et al. 2003).

The concept of ecological memory helps us think about regions of spatial monocultures and the role of biocultural refugia in the renewal of ecosystem services (cf. Nyström and Folke 2001, Bengtsson et al. 2003, Barthel et al. 2013a). In the context of dramatic disturbance - fire ravages a landscape, the land use changes, or glaciers cover the land - ecological memory depends on three factors: the diversity of mobile species that provide critical ecological material (seeds, eggs, pollen) to a disturbed area; the diversity and quantity of surviving organisms in the disturbed area (large trees that survive fire, seeds, rhizomes or other propagates that remain in the soil and take advantage of the disturbance); and the physical morphology of the landscape, including migration routes and diversity of refugia from which novel ecological material can be vectored into the disturbed area (Lundberg and Moberg 2003, Bodin and Norberg 2007, Bodin and Saura 2010). In anthropogenic biomes (Ellis and Rammankutty 2008), dominated by industrial monocultures, biocultural refugia increase spatial diversity and can function as source areas for many species threatened by extinction. Such biocultural refugia can also extend spatial memory by providing bridges for the migration of threatened species across agricultural heartlands. For instance, Las Dehesas de Sierra Morena in the South of Spain (mentioned above) are linked to summer grazing areas to the north by a network of pastoral corridors (including The Conquense Drove Road elaborated by Oteros-Rozas et al. 2013), which originated in traditional seasonal pastoral activity (Emanuelsson 2010, Oteros-Rozas et al. 2013). The corridors, from twenty to seventy-five meters in width, crisscross the Iberian Peninsula and cover about $0.83 \%$ of its land area. They are bridges of diversity and resilience for a wide variety of species, including the sheep whose grazing keeps them open. Although modern transportation technology has come close to replacing the month-long journey on foot between pastures, the recent financial crisis and uncertain prices of fodder and fossil fuels have prompted shepherds to take up traditional practices again (Oteros-Rozas et al. 2013).

A landscape with reduced diversity and lacking access to refugia is vulnerable to disturbances like fires, infestations of pests, rainfall fluctuation, and climate change; it might respond by changing in quality, so that the ecosystem services it provides change (Foley et al. 2005, Enfors and Gordon 2008, Gordon et al. 2008). In this context, biocultural refugia are critical for food sovereignty, biodiversity management, and those ecosystem services vital to the long-term success of agriculture (as called for by Godfray 2011). Because biocultural refugia contain such a broad array of experience from deep history of European agriculture, and because they serve as genetic and cultural reservoirs, they increase the range of potential responses to external environmental stressors, rapidly fluctuating markets, and cascading energy, financial, and political crises. They preserve knowledge of how to cultivate the range of species suitable to a changing habitat, real-world farming practices that can be mobilized to meet the needs of a changing world.

\section{Biocultural Refugia and Ecosystem Restoration}

The concept of biocultural refugia also pertains to the field of ecosystem restoration, which has for a very long time tested ways to apply traditional practices to the restoration of degraded ecosystems and has sought an integrated theory of linked human and environmental systems (Brinck et al. 1988, Foster et al. 2003). The concept can help develop baselines 
for decisions that are more politically, socially, and historically informed. All too often, plans for the repair or reconstruction of an ecosystem are based on a "selective memory" constrained by what information is readily available, technical considerations, and cultural assumptions about which particular landscape is authentic and which resources are desirable.

The case of a restoration project in the Jutland region of Denmark, near the North Sea, illustrates the role of selective memory in landscape management (Olwig 2008). At the beginning of the 1900s, a choice was made from several possible uses for what previously had been a dynamic landscape dominated by a heathland/forest succession cycle. The choice was based upon values associated with the emerging tourist industry: the land was conserved as heathland for its "beauty and degree of wilderness", (Olwig 2008, see for instance Det danske hedesellskap/The Danish Heath Association). Before the 1900s, this marginal landscape had been valued as an extension of the agricultural capacity of an impoverished region (Olwig 2008, Emanuelsson 2010). Its exploitation followed a carefully gauged cycle: the forest was cut down gradually, both for timber and to open space for crop production (Olwig, 2008). The fields became pastures and then were allowed to return to forest, which restored soil nutrition. The cycle took several decades (Emanuelsson 2010). Proponents of nature tourism and conservation argued that the open heath landscape was the "original" type of cover, and succeeded in protecting the landscape at that stage. The traditional management cycle of a dynamic domesticated landscape was broken (Olwig 2008, for more examples see also Higgs 2003). A landscape that had been managed according to a traditional temporal dynamic was "restored" according to a partial and selective memory that correlated with the aesthetic values of the emerging tourist industry. Enhanced biodiversity was not perceived as a worthy objective.

"Moving back" in order to "reconstruct" historical ecosystems can have its pitfalls, since all learning from history takes place in the context of contemporary values (Halbwachs 1925, Ernstson and Sörlin 2009). What is the goal of reconstruction: aesthetics, perceived originality, biodiversity? Any particular goal, such as the restoration of a wetland ecosystem that earlier was cleared for agriculture, is associated with a set of values which drive reorganization of the particular landscape. For instance, wetlands were historically managed to increase the productivity of biomass (e.g., by letting cattle feed on the swampy shore lines); in contrast, some recent wetland restoration seeks to provide habitat and to mitigate nitrogen and phosphorous leakages and other negative effects of intensive agriculture and forestry. A number of goals can be served in planning and implementing a given reconstruction.

A model for the alignment of ecosystem restoration with biocultural refugia is found in Japanese satoyama landscapes, where human stewardship promotes biodiversity (E. Andersson and S. Barthel unpublished manuscript). "Satoyama" refers to a mosaic of ecosystems - woodlands, farms, wetlands, paddies, and grasslands - shaped by human habitation (Takeuchi et al. 2003). Management practices connect the elements of the mosaic: compost and waste fertilize fields and paddies; coppicing and pollarding in the woodlands provide wood for charcoal and fodder for livestock. The creation and maintenance of many patches of compatible land-use in these mosaic landscapes produces a wide range of potential refugia. The small scale of the patches is conducive to the movement of species, particularly between paddy fields, ponds, and wetlands (Katoh et al. 2009).

Every agricultural region has had a traditional smallholder system that is the equivalent of the satoyama system. Of course, species and cultural practices differ, but any such system could be adapted for ecosystem restoration. Historical practices, properly understood, are well suited to contemporary needs, as the permaculture movement has discovered (Berkes et al. 2000). It must be recognized that "old" solutions are links to various forms of tacit knowledge that are transmitted by habits of practice and of mind (Polyani 1966, Sensiper 1998), particularly in the realm of food production and processing (Scott 1998, Crumley 2000, Agrawal 2002, Nazarea 2006, Barthel et al. 2013a).

When considering restoration of an ecosystem to a perceived former state, the goal of the project must be examined along with any new scientific and technical knowledge. Biocultural refugia can be used to challenge assumptions heretofore taken for granted (Campbell et al. 2009), such as the idea that a place cannot support both biodiversity and food production (Phalan et al. 2011). The broader perspective of biocultural refugia reveals the possibility of achieving both goals by pursuing more extensive collaboration with farmers oriented toward historically informed and ecologically sound smallholder practices (Benton et al. 2003, Antrop 2005, Tscharntke et al. 2005, Perfecto and Vandermeer 2010, Chapell and LaValle 2009, De Schutter 2010, Horlings and Marsden 2011). These practices are the products of coping with changing climate and ecosystem states, from wet to dry to wet again, from warm to cold and back to warm. Some biocultural refugia preserve farming practices developed on marginal lands: making terraces on sloping terrain, conserving moisture under subdesert-like conditions, or grazing strategies in terrain with poor soil. Learning from biocultural refugia can help to avoid mistakes by taking into account feedbacks discovered using different management practices over very long periods (Barthel et al. 2013a).

\section{Some broader connections to the theme of biocultural refugia}

It should be clear from the preceding text that the ongoing systematic selection and storage of seed in places like the Svalbard storage facility must be accompanied by the 
collection, analysis, and systematization of the social and technical knowledge needed for their cultivation. The preservation of TEK in particular requires safeguarding biocultural refugia, not merely as places of historic interest, but in order to make a variety of management tools and practices available as strategic choices in times of change and crisis. As we move further into the Anthropocene, the geological period dominated by human impacts on the planet (Steffen et al. 2011), the conditions under which production of food, feed, fibers, and fuel take place are rapidly changing.

The importance of biocultural refugia extends beyond local agricultural production to important issues connected to the cultural, value, and ethical dimensions of agricultural practices. The increasing interest in ecotourism, for instance, connects recreation to farm practices through the desire of an increasingly urban population to make an emotional connection to the environment (Folke et al. 2011), sometimes referred to as "biophilia", an intense interest in caring for the biological world. Ecotourism also engages the increasingly general concern about the relationship between rural and urban areas.

Biocultural refugia offer historical solutions to a wide range of challenges emerging from changing conditions and in need of innovative approaches, such as management of water flows and biological methods of waste management in addition to ecosystem services alluded to earlier. Biocultural refugia can contribute to analysis of issues at different scales, as in the examination of community biocultural landscapes; research into knowledge production and learning for sustainable landscapes, including the use of social-ecological systems as laboratories (Angelstam et al. 2013); examination of legal frameworks for biosphere reserves as learning sites for sustainable development (Elbakidze et al. 2013); and the study of many issues related to agricultural and forestry practices.

\section{CONCLUSION}

Neither the goal of reducing agriculture's pressure on biodiversity nor the goal of increasing food production for a growing population can be achieved in isolation (Godfray 2011). Often, strategies must be tailored to a landscape in order to integrate both goals. Connecting the literature of social memory to the role of TEK for management of biodiversity in domesticated landscapes helps us understand that the diversity of cultural practices in traditional agriculture is closely linked to the maintenance of entire landscapes, habitats and the survival of locally evolved species. Genotypes, landscape features, artifacts, habits, oral traditions and selforganized systems of rules are components that carry and transmit TEK between people and across cohorts. We argue that the rich biodiversity of many regionally distinct cultural landscapes has been maintained through a mosaic of management practices, developed in the context of the relationship between local environmental fluctuations and profitable farmers. The intimate connection of TEK to particular landscapes is manifested in the small-scale mosaic of habitats that allow species to flourish and adapt to change. Nurturing such biocultural refugia will improve possibilities for future generations to access the rich fund of experience with biodiversity and ecosystem functioning that is embedded in human societies, traditions, and cultures (Berkes and Folke 1998). However, memory carriers of TEK and related practices are threatened by processes of land-grabbing and by the current form of industrialized agriculture under way worldwide. In Europe's agricultural landscapes, an accelerating loss of traditional knowledge and practices is resulting in an erosion of biodiversity and loss of regulating ecological services. Therefore, the strategy presented in this paper favors land-sharing in those regions with a long history of agriculture. The alternative - land-sparing — does less to conserve biodiversity in such regions.

Standardized monocultures of food production are increasingly vulnerable to environmental shocks, and an array of social impacts associated with cascading energy, financial, or political crises. The diverse portfolio of practices maintained in biocultural refugia, along with reserves, national parks, and other protected habitats, can reduce that vulnerability by allowing for spatial diversity that revive vital ecosystem services and biodiversity in landscapes of food production (Colding and Folke 2001, Elmqvist et al. 2003, Bengtsson et al. 2003, Tengö et al. 2007). This paper does not advocate a museum-like preservation of pre- or earlyindustrial-era agricultural processes and institutions. Our point is that society should incorporate in future strategies and practices the hard-won experiences retained in biocultural refugia (Antrop 2005, Baleé 2006, Crumley 2007, Costanza 2007, Libby and Steffen 2007, Dearing 2008, Guttman-Bond 2010). Indeed, the environmental challenges of the near future will require every resource at our disposal (Steffen et al. 2011). The integrated approach we advocate works with regional landscape ecologies and supports local food sovereignty. As societies everywhere seek solutions to the challenges of the emerging Anthropocene Era, a key lesson for policy-makers is that guarding the functioning of interlinked biocultural diversity is a critical strategy for stewardship of the biosphere (Barthel et al. 2013a).

Responses to this article can be read online at: http://www.ecologyandsociety.org/issues/responses. $\mathrm{php} / 6207$

\section{Acknowledgments:}

Thanks Chris Potter for text editing. Thanks to Carl Folke, Jacob von Heland, and Cibele Queiroz for being part of developing the concept in a meeting six years ago at the Royal 
Academey of Sciences, that finally went all the way to publication. This paper has benefited from discussions with colleagues within the research projects and networks IHOPE (Integrated History and Future of People on Earth), WHEN (World Historical Ecology Network), and the Food Group at Stockholm Resilience Centre, coordinated by Mike Jones.

\section{LITERATURE CITED}

Agrawal, A. 2002. Indigenous knowledge and the politics of classification. Social Science Journal 54:287-297.

Alcorn, J. B., and V. M. Toledo. 1998. Resilient resource management in Mexico's forest ecosystems: the contribution of property rights. In F. Berkes and C. Folke, editors. Linking Social and Ecological Systems: Management Practices and Social Mechanisms for Building Resilience. Cambridge University Press, Cambridge, U. K.

Almekinders, C. J. M., and A. Elings. 2001. Collaboration of farmers and breeders: participatory crop improvement in perspective. Euphytica 122:425-438. http://dx.doi.org/10.1023/ A:1017968717875

Altieri, M. A., L. C. Merrick, and M. K. Anderson. 1987. Peasant agriculture and the conservation of crop and wild plant resources. Conservation Biology 1:49-58. http://dx.doi. org/10.1111/j.1523-1739.1987.tb00008.x

Andersson, E., S. Barthel, and K. Ahrné. 2007. Measuring social-ecological dynamics behind the generation of ecosystem services. Ecological Applications 17(5): 1267-1278. http://dx.doi.org/10.1890/06-1116.1

Angelstam, P., M. Elbakidze, R. Axelsson, M. Dixelius, and J. Törnblom. 2013. Knowledge Production and Learning for Sustainable Landscapes: Seven Steps using Social-Ecological Systems as laboratories. Ambio 42(2):116-128. http://dx.doi. org/10.1007/s13280-012-0367-1

Antrop, M. 2005. Why landscapes of the past are important for the future. Landscape and Urban Planning 70 (1): 21-34. http://dx.doi.org/10.1016/j.landurbplan.2003.10.002

Avery, A. 2007. 'Organic abundance' report: fatally flawed. Renewable Agriculture and Food Systems 22(4): 321-323.

Balmford, A., R. E. Green, and J. P. W. Scharlemann. 2005. Sparing land for nature: exploring the potential impact of changes in agricultural yield on the area needed for crop production. Global Change Biology 11:1594-1605. http://dx. doi.org/10.1111/j.1365-2486.2005.001035.x

Baleé, W. 2006. The Research Program of Historical Ecology. Annual Review of Anthropology 35:75-98. http://dx.doi. org/10.1146/annurev.anthro.35.081705.123231

Báldi, A., P. Batáry, and D. Kleijn. 2012. Effects on grazing and Biogeographic regions on grassland biodiversity in Hungary-Analyzing the assemblages of 1200 species.
Agriculture, Ecosystems and the Environment 166:28-34. http://dx.doi.org/10.1016/j.agee.2012.03.005

Barber, E. W., and P. T. Barber. 2004. When They Severed Earth from Sky: How the Human Mind Shapes Myth. Princeton University Press, Princeton, USA.

Barthel, S., C. L. Crumley, and U. Svedin. 2013a. Bio-cultural Refugia - Safeguarding Diversity of Practices For Food Security and Biodiversity. Global Environmental Change 23:1142-1152.

Barthel, S., J. Parker, and H. Ernstson. 2013. Food, Memories and Green Space in Cities: A Resilience Lens on Gardens and Urban Environmental Movements. Urban Studies 86:156-166.

Barthel, S., C. Folke, and J. Colding. 2010. Social-Ecological Memory in Urban Gardens - Retaining the capacity for management of ecosystem services. Global Environmental Change 20(2):255-265. http://dx.doi.org/10.1016/j.

gloenvcha.2010.01.001

Barthel, S., J. Colding, C. Folke, and T. Elmqvist. 2005. History and local management of a biodiversity rich urban cultural landscape. Ecology and Society 10 (2):10. [online] URL http://www.ecologyandsociety.org/vol10/iss2/art10

Beaufoy, G., D. Baldock, and J. Clark. 1994. The nature of Farming: low intensity farming systems in nine European countries. Institute for European Environmental Policy, London, U. K.

Bengtsson, J., J. Ahnström, and A-C. Weibull. 2005. The effects of organic agriculture on biodiversity and abundance: a metaanalysis. Journal of Applied Ecology 42:261-269. http:// dx.doi.org/10.1111/j.1365-2664.2005.01005.x

Bengtsson, J., P. Angelstam, T. Elmqvist, U. Emanuelsson, C. Folke, M. Ihse, F. Moberg, M. Nyström. 2003. Reserves, Resilience and Dynamic Landscapes. Ambio 32(6):389-396.

Benton, T. G., J. A. Vickery, and J. D. Wilson. 2003. Farmland biodiversity: is habitat heterogeneity the key? Trends in Ecology and Evolution 18(4):182-188.

Berkes, F., and C. Folke, editors. 1998. Linking Social and Ecological Systems: Management Practices and Social Mechanisms for Building Resilience. Cambridge University Press, Cambridge, UK.

Berkes, F., J. Colding, and C. Folke. 2000. Rediscovery of traditional knowledge as adaptive management. Ecological Applications 10:1251-1262. http://dx.doi.org/10.1890/1051-0761 (2000)010[1251:ROTEKA]2.0.CO;2

Berkes, F., and C. Folke. 2002. Back to the Future: Ecosystem Dynamics and Local Knowledge. In Gunderson, L. H. and C. S. Holling, editors. Panarchy; Understanding Transformations in Human and Natural Systems. Island Press, Washington DC, USA. 
Berkes, F., J. Colding, and C. Folke, editors. 2003. Navigating Social-Ecological Systems, Building resilience for complexity and change. Cambridge University Press, NY, USA. http:// dx.doi.org/10.1017/CBO9780511541957

Biesmeijer, J. C., S. P. M. Roberts, M. Reemer, R. Ohlemüller, M. Edwards, T. Peeters, A. P. Schaffers, S. G. Potts, R. Kleukers, C. D. Thomas, J. Settele, and W. E. Kunin. 2006. Parallel declines in pollinators and insect-pollinated plants in Britain and the Netherlands. Science 313:351-354.

Bodin, Ö., and J. Norberg. 2007. A network approach for analyzing spatially structured populations in fragmented landscape. Landscape Ecology 22:31-44. http://dx.doi. org/10.1007/s10980-006-9015-0

Bodin, Ö., and S. Saura. 2010. Ranking individual habitat patches as connectivity providers: Integrating network analysis and patch removal experiments. Ecological Modelling 221: 2393-2405. http://dx.doi.org/10.1016/j. ecolmodel.2010.06.017

Boillat, S., and F. Berkes. 2013. Perception and interpretation of climate change among Quechua farmers of Bolivia: indigenous knowledge as a resource for adaptive capacity. Ecology and Society 18(4): 21. http://dx.doi.org/10.5751/ ES-05894-180421

Brink, P. L., M. Nilsson, and U. Svedin. 1988. Ecosystem redevelopment. Ambio 17(2):84-89.

Broadbent, N. D. 2010. Lapps and Labyrinths: Saami Prehistory, Colonization and Cultural Resilience. Smithsonian Institution Scholarly Press, USA.

Campbell, L. M., N. J. Gray, E. L. Hazen, and J. M. Shackeroff. 2009. Beyond baselines: rethinking priorities for ocean conservation. Ecology and Society 14(1):14. http://www. ecologyandsociety.org/vol14/iss1/art14

Carpenter, S. R., and C. Folke. 2006. Ecology for transformation. Trends in Ecology and Evolution 21: 309-315. http://dx.doi.org/10.1016/j.tree.2006.02.007

Castell, M. 2009. Communication Power. Oxford University Press, NY., USA.

Chappell, M. J., and A. L. LaValle. 2009. Food security and biodiversity: can we have both? An agro-ecological analysis. Agriculture and Human Values 1-24.

Climo, J. J., and M. G. Cattell. 2002. Social Memory and History: Anthropological Perspectives. AltaMira Press, Walnut Creek, CA., USA.

Colding, J., and C. Folke. 2001. Social taboos: "Invisible" systems of local resource management and biological conservation. Ecological Applications 11:584-600.

Connerton, P. 1989. How Societies Remember. Cambridge University Press, Cambridge, U. K. http://dx.doi.org/10.1017/ CBO9780511628061
Cordell, D., J-L. Drangert, and S. White. 2009. The story of Phosphorus: Global food security and food for thought. Global Environmental Change 19: 292-305. http://dx.doi.org/10.1016/ j.gloenvcha.2008.10.009

Costanza, R. 2007. The Need for a Transdisciplinary Synthesis of History. Ambio 37(7): 521.

Crumley, C. L. 2007. Historical Ecology: Integrated Thinking at Multiple Temporal and Spatial Scales. In: Hornborg, A. \& Crumley C. L., editors. The World System and the Earth System-Global Socioenvironmental Change and Sustainability since the Neolithic. Left Coast Press, Walnut Creek, CA., USA.

Crumley, C. L. 2000. From Garden to Globe: Linking time and space to meaning and memory. In R. j. McIntosh, J A. Tainter, S. K. McIntosh, editors. The Way the Wind BlowsClimate, History and Human Action. Historical Ecology series, Colombia University Press. NY., USA.

Crumley, C. L. 1994. Historical ecology: Cultural Knowledge and Changing Landscapes. School of American Research Press, Santa Fe, NM., USA.

Crumley, C. L. 1993. Analyzing Historic Ecotonal Shifts. Ecological Applications 3(3):377-384. http://dx.doi. org/10.2307/1941906

Dahlberg, K. A. 1993. Regenerative food systems: broadening the scope and agenda of sustainability. In P. Allen, editor. Food for the future: conditions and contradictions of sustainability. Wiley, NY., USA.

Dahlström, A., A-M. Iuga, and T. Lennartson. 2013. Managing Biodiversity Rich Hay Meadows in the EU: a Comparison of Swedish and Romanian Grasslands. Environmental Conservation 40(0):1-12. http://dx.doi.org/10.1017/ $\underline{\mathrm{S} 0376892912000458}$

Davidson-Hunt, I. J., C. J. Idrobo, R. D. Pengelly, and O. Sylvester. 2013. Anishinaabe adaptation to environmental change in northwestern Ontario: a case study in knowledge coproduction for nontimber forest products. Ecology and Society 18(4): 44. http://dx.doi.org/10.5751/ES-06001-180444

Dearing, J. A. 2008. Landscape change and resilience theory: a palaeoenvironmental assessment from Yunnan, SW China. The Holocene 18 (1):117-127. http://dx.doi.org/10.1177/0959683607085601

De Schutter, O., and G. Vanloqueren. 2011. The new green revolution: How twenty first century science can feed the world. Solutions 2:(4).

De Schutter, O. 2010. Report submitted by the Special Rapporteur on the right to food. United Nations, Human Rights Council, sixteenth session, Agenda item 3, A/ $\mathrm{HRC} / 16 / 49$. 
DeLind, L. B. 2002. Place, work and civic agriculture: common fields for cultivation. Agriculture and Human values 19:217-224. http://dx.doi.org/10.1023/A:1019994728252

Dominkovic, K, L. 2007. Traditional Agriculture and Rural Living in Croatia: Compatible with the new Common Agricultural Policy? A dissertation submitted to the faculty of the University of North Carolina at Chapel Hill in partial fulfillment of the requirements for the degree of Doctor of Philosophy in the Department of Anthropology. Chapel Hill, NC., USA.

Elbakidze M., T. Hahn, V. Mauerhofer, P. Angelstam, and R. Axelsson. Legal Framework for Biospehere as Learning Sites for Sustainable Development: A Comparative Analysis of Ukraine and Sweden. Ambio 42(2):174-187.

Ellis, C. E., and N. Ramankutty. 2008. Putting people on the map: Anthropogenic biomes of the world. Frontiers of Ecological Environment 6(8):439-447. http://dx.doi. org/10.1890/070062

Elmqvist, T., C. Folke, M. Nyström, G. Peterson, J. Benktsson, B. Walker, and J. Norberg. 2003. Response diversity, ecosystem change, and resilience. Frontiers of Ecological Environment 1 (9):488-494.

Emanuelsson, U. 2010. Rural Landscapes of Europe-How Man has shaped European Nature. Fälth and Hässler, Värnamo, Sweden.

Emsley, J. 2001. Enriching the earth: Fritz Haber, Carl Bosch, and the transformation of world food. Nature 410 (6829):633-634.

Evans, A. 2009. The Feeding of the Nine Billion: Global food security for the $21^{s t}$ century. Royal Institute of International Affairs, London, U. K.

Enfors, E., and L. J. Gordon.2008. Dealing with drought: The challenge of using water system technologies to break dryland poverty traps. Global Environmental Change 18:607-616. http://dx.doi.org/10.1016/j.gloenvcha.2008.07.006

Ericksen, P. J. 2008. Conceptualizing food systems for global environmental change research. Global Environmental Change 18 (1):234-245. http://dx.doi.org/10.1016/j.

gloenvcha.2007.09.002

Eriksson, O., S. A. O. Cousins, and H. H. Bruun. 2002. Landuse history and fragmentation of traditionally managed grasslands in Scandinavia. Journal of Vegetation Science 13:743-748. http://dx.doi.org/10.1111/j.1654-1103.2002.tb02102. $\underline{x}$

Ernstson, H., and S. Sörlin. 2009. Weaving protective stories: connective practices to articulate holistic values in the Stockholm National Urban Park. Environmental Planning A 41 (6):1460-1479. http://dx.doi.org/10.1068/a40349
Eyzaguirre, P. B., and O. F. Linares. 2004. Home Gardens and Agrobiodiversity. Smithsonian Books, Washington DC., USA.

Ferrier, S., G. V. N. Powell, K. S. Richardson, G. Manion, J. M. Overton, T. F. Allnutt, S. E. Cameron, K. Mantle, N. D. Burgess, D. P. Faith, J. F. Lamoreux, G. Kier, R. J. Hijmans, V. A. Funk, G. A. Cassis, B. L. Fisher, P. Flemons, D. Lees, J. C. Lovett, and R. S. A. R. Van Rompaey. 2004. Mapping more of terrestrial biodiversity for global conservation assessment. BioScience 54(12):1101. http://dx.doi. org/10.1641/0006-3568(2004)054[1101:MMOTBF]2.0.CO;2

Foley, J. A., R. DeFries, and G. P. Asner, et al. 2005. Global consequences of land use. Science 309(5734):570-74. http:// dx.doi.org/10.1126/science.1111772

Folke, C., C. S. Holling, and C. Perrings. 1996. Biological diversity, ecosystems and the Human Scale. Ecological Applications 6(4):1018-1024. http://dx.doi.org/10.2307/2269584

Folke, C., J. Colding, and F. Berkes. 2003. Synthesis: building resilience and adaptive capacity in social-ecological systems. In F. Berkes, J. Colding, and C. Folke, editors. Navigating Social-Ecological Systems: Building Resilience for Complexity and Change. Cambridge University Press, Cambridge, UK. http://dx.doi.org/10.1017/CBO9780511541957.020

Folke, C., Å. Jansson, J. Rockström et al. 2011. Reconnecting to the Biosphere. 2011. Ambio 40:719-738. http://dx.doi. org/10.1007/s13280-011-0184-y

Food and Agriculture Organization (FAO). 2006. The state of food insecurity in the world 2006: Eradicating world hunger -taking stock ten years after the World Food Summit. Food and Agriculture Organization. Rome, Italy.

Food and Agriculture Organization (FAO). 2008. The state of food insecurity in the world 2008: High food prices and food security — threats and opportunities. Food and Agriculture Organization. Rome, Italy.

Foster, D., F. Swanson, J. Aber, I. Burke, N. Broakaw, D. Tilman, and A. Knapp. 2003. The importance of land-use legacies to ecology and conservation. Bioscience 53 (1):77-88. http://dx.doi.org/10.1641/0006-3568(2003)053[0077:TIOLUL] 2.0.CO;2

Fraser, E. D. G., and A. Rimas. 2010. Empires of Food. Feast, Famine and the Rise and Fall of Civilizations. Random House Books, NY., USA.

Friel, S., M. Chopra, and D. Satcher. 2007. Unequal weight: equity oriented policy responses to the global obesity epidemic. British Medical Journal 335(7632):1241-1243. http://dx.doi.org/10.1136/bmj.39377.622882.47

Frison, E. A., I. F. Smith, T. Johns, J. Cherfas, and P. B. Eyzaguirre. 2006. Agricultural biodiversity, nutrition, and 
health: Making a difference to hunger and nutrition in the developing world. Food and Nutrition Bulletin 27 (2):167-179.

Gadgil, M., F. Berkes, and C. Folke. 1993. Indigenous knowledge for biodiversity conservation. Ambio 22:151-156.

Godfray, H. C. J. 2011. Food and Biodiversity. Science 333:1231-1232. http://dx.doi.org/10.1126/science.1211815

Gómez-Baggethun, E., E. Corbera and V. Reyes-García 2013. Traditional ecological knowledge and global environmental change: research findings and policy implications. Ecology and Society 18(4):72. http://dx.doi.org/10.5751/ES-06288-180472

Gómez-Baggethun, E., S. Mingorría, V. Reyes-García, L. Calvet, and C. Montes. 2010. Traditional Ecological Knowledge Trends in the Transition to a Market Economy: Empirical Study in the Donana Natural Areas. Conservation Biology 24( 3):721-729.

Gómez-Baggethun, E., V. Reyes-Garcia, P. Olsson, and C. Montes. 2012. Traditional ecological knowledge and community resilience to environmental extremes: A case study in Donana, SW Spain. Global Environmental Change 22(3):640-650. http://dx.doi.org/10.1016/j.gloenvcha.2012.02.005

Gómez-Baggethun, E., and V. Reyes-Garcia. 2013. Reinterpreting change in traditional ecological knowledge. Human Ecology 41(4):643-647 http://dx.doi.org/10.1007/ s10745-013-9577-9

Gordon, L. J., G. D. Pettersen, and E. M. Bennet. 2008. Agricultural modifications of hydrological flows create ecological surprises. Trends in Ecology \& Evolution 23 (4):211-219. http://dx.doi.org/10.1016/j.tree.2007.11.011

Green, E. R., J. S. Cornell, P. W. J. Scharlemenn, A. Balmford. 2005. Farming and the fate of wild Nature. Science 307:550-555. http://dx.doi.org/10.1126/science.1106049

Gronenborn, D. 2009. Climate fluctuations and trajectories to complexity in the Neolithic: towards a theory. Documenta Praehistorica XXXVI (2009). http://dx.doi.org/10.4312/ dp.36.5

Gunderson, L. and C. S. Holling, editors. 2002. Panarchy: Understanding transformations in human and natural systems. Island Press, Washington D. C., USA.

Gunn, J. D. 1994. Climate and biocultural diversity. In: Crumley C. L. editor. Historical Ecology: Cultural knowledge and changing landscapes. School of American research press, Santa Fe, NM., USA.

Gurr, G. M., S. D. Wratten, and J. M. Luna. 2003. Multifunction agricultural biodiversity: pest management and other benefits. Basic and Applied Ecology 4(2):107-116. http://dx. doi.org/10.1078/1439-1791-00122
Guttman-Bond, E. 2010. Sustainability out of the past: How archeology can save the planet. World Archeology 42 (3):355-366. http://dx.doi.org/10.1080/00438243.2010.497377

Haffer, J. 1982. General aspects of refuge theory. In G. T. Prance, editor, Biological diversification in the tropics. Columbia University Press, NY, USA.

Halbwachs, M. 1925. On Collective Memory. University of Chicago Press, Chicago, USA, [1952].

Hanna, S., C. Folke, and K-G. Mäler. 1996. Rights to Nature: Ecological, Economic, Cultural, and Political Principles of Institutions for the Environment. Island Press, Washington D. C., USA.

Harvey, D. 2010. The Enigma of Capital and the Crisis of Capitalism. Oxford University Press, Oxford, U. K.

Higgs, E. 2003. Nature by Design: People, Natural Process and Ecological Restoration. MIT Press; Cambridge, USA. http://dx.doi.org/10.1525/cag.2006.28.2.135

Horlings, L. G., and T. K. Marsden. 2011. Towards the real green revolution? Exploring the conceptual dimensions of a new ecological modernisation of agriculture that could 'feed the world'. Global Environmental Change 21(2):441-452. http://dx.doi.org/10.1016/j.gloenvcha.2011.01.004

Ingram, J. S. I., P. J. Gregory, and A-M. Izac. 2008. The role of agronomic research in climate change and food security policy. Agriculture, Ecosystems and Environment 126:4-12. http://dx.doi.org/10.1016/j.agee.2008.01.009

International Assessment of Agricultural Knowledge Science and Technology for Development (IAASTD). 2009. Agriculture at a crossroads: international assessment of agricultural knowledge, science and technology for development. Washington, D. C., Island Press, USA.

Jarvis, D., and T. Hodgkin. 1999. Wild relatives and crop cultivars: detecting natural introgression and farmer selection of new genetic combinations in agroecosystems. Molecular Ecology 8:159-173. http://dx.doi.org/10.1046/

j.1365-294X.1999.00799.x

Joffre, R., J. Vacher, C. de los Llanos, and G. Long. 1988. The dehesa: an agrosilvopastoral system of the mediterranean region with special reference to the Sierra Morena Area of Spain. Agroforestry Systems 6:71-96.

Kahn, P. 2002. Children's affiliations with nature: structure, development, and the problem of environmental generational amnesia. Children and nature: Psychological, sociocultural, and evolutionary investigations 93-116.

Katoh, K., S. Sakai, and T. Takahashi. 2009. Factors maintaining Species Diversity in Satoyama, A Traditional Agricultural Landscape of Japan. Biological Conservation 142:1930-1936. http://dx.doi.org/10.1016/j.biocon.2009.02.030 
Kaplan, J, O., K, M. Krumhardt, N. Zimmermann. 2009. The prehistoric and preindustrial deforestation of Europe. Quaternary Science Review 28:3016-3034. http://dx.doi. org/10.1016/j.quascirev.2009.09.028

Kearns, C. A., D. W. Innoye, and N. M. Waser. 1998. Endangered mutualism, the conservation of plant-pollinator interactions. Annual Review of Ecology and Systematic 29:83-112. http://dx.doi.org/10.1146/annurev.ecolsys.29.1.83

Klein, A. -M., B. E. Vaissiere, J. H. Cane, I. Steffan-Dewenter, S. A. Cunningham, C. Kremen, and T. Tscharntke. 2007. Importance of pollinators in changing landscapes for world crops. Proceedings of the Royal Society of London, Series B, Biological Sciences 274:303-313. http://dx.doi.org/10.1098/ rspb.2006.3721

Lansing, S. J. 2003. Complex adaptive systems. Annual Review of Anthropology 32:183-204. http://dx.doi.org/10.1146/ annurev.anthro.32.061002.093440

Lansing, S. J. 1991. Priests and Programmers, Technologies of Power in the Engineered Landscape of Bali. Princeton University Press, NJ., USA. http://dx.doi.org/10.2307/3106660

Lawrence, A. 2009. The first cuckoo in winter: phenology, recording, credibility and meaning in Britain. Global Environmental Change 19:173-179. http://dx.doi.org/10.1016/ j.gloenvcha.2009.01.006

Leopold, A. 1949. A Sand County Almanac. Oxford University Press, Oxford, U. K.

Levin, S. A. 1998. Ecosystems and the Biosphere as Complex Adaptive Systems. Ecosystems 1:431-436. http://dx.doi. org/10.1007/s100219900037

Libby, R., and W. Steffen. 2007. History for the Anthropocene. History Compass 5(5):1694-1719.

Lin, B, B., J. Chappell, J. Vandermeer, et al. 2011. Effects of industrial agriculture on climate change and the mitigation potential of small-scale agro-ecological farms. CAB Reviews: Perspectives in Agriculture, Veterinary Science, Nutrition and Natural Resources 6(20):1-18.

Lindborg, R., and O. Ericksson. 2004. Historical Landscape Connectivity Affects Present Plant Species Diversity. Ecology 85(7):1840-1845. http://dx.doi.org/10.1890/04-0367

Low, B., E. Ostrom, C. Simon, J. Wilson. 2003. Redundancy and diversity: do they influence optimal management. In F. Berkes, J. Colding and C. Folke, editors. Navigating SocialEcological Systems: Building Resilience for Complexity and Change. Cambridge University Press, Cambridge, U. K. http:// dx.doi.org/10.1017/CBO9780511541957.007

Lundberg, J., and F. Moberg. 2003. Mobile link organisms and ecosystem functioning: implications for ecosystem resilience and management. Ecosystems 6:87-98. http://dx. doi.org/10.1007/s10021-002-0150-4
Maffi, L., and E. Woodley. 2010. Biocultural Diversity Conservation. A global source book. Earthscan, London, UK.

McKenna, J., R. J. Quinn, D. J. Donnelly, and J. A. G. Cooper. 2008. Accurate mental maps as an aspect of local ecological knowledge (LEK): a case study from Lough Neagh, Northern Ireland. Ecology and Society 13 (1):13. [online] URL: http// www.ecologyandsociety.org/vol13/iss1/art13/

McIntosh, R, J., J A. Tainter, S. K. McIntosh, editors. 2003. The Way the Wind Blows-Climate, History and Human Action. Historical Ecology series, Colombia University Press. NY., USA.

McMichael, P. 2009. Banking on Agriculture: an assessment of the 2008 World Bank Report. Journal of Agrarian Studies 9(2):235-246.

McMichael, P. 2011. Food systems sustainability: Questions of environmental governance in the new world (dis)order. Global Environmental Change 21(3):804-812. http://dx.doi. org/10.1016/j.gloenvcha.2011.03.016

Mikulcak, F., J. Newig, A. I. Milncu, T. Hartel, and J. Fischer. 2013. Integrating rural development and biodiversity conservation in Central Romania. Environmental Conservation 40(2):129-137. http://dx.doi.org/10.1017/S0376892912000392

Misztal, B, A. 2003. Theories on Social Remembering. Open University Press, Berkshire, U. K.

Moreno, G., and F. J. Pulido. 2008. The Functioning, Management and Persistence of Dehesas. Advances in Agroforestry 6:127-160. http://dx.doi.org/10.1007/978-1-4020-8272-6 7

Nabhan, G. P. 1997. Cultures of Habitat. Counterpoint, Washington DC., USA.

Nabhan, G. P. 2008. Where Our Food Comes From. Island Press, Washington DC., USA.

Nazarea, D. V. 2006. Local knowledge and memory in biodiversity conservation. Annual Review of Anthropology 35:317-335. http://dx.doi.org/10.1146/annurev. anthro.35.081705.123252

Nazarea, D. V. 1998. Cultural Memory and Biodiversity. Arizona University Press, Tuscon, USA.

Negri, V. 2003. Landraces in central Italy: Where and why they are conserved and perspectives for their on-farm conservation. Genetic Resources and Crop Evolution . 50 ( 8):871-885.

Negri, V. 2005. Agro-biodiversity conservation in Europe: Ethical issues. Journal Of Agricultural and Environmental Ethics 18(1):3-25. http://dx.doi.org/10.1007/s10806-004-3084-3

Netting, R. Mc. C. 1993. Smallholders, Householders: Farm Families and the Ecology of Intensive, Sustainable Agriculture. Stanford University Press, Stanford, CA., USA. 
Norgaard, R. 2010. Ecosystem service: From eye-opening metaphor to complexity blinder. Ecological Economics 69 (6):1219-1227. http://dx.doi.org/10.1016/j.ecolecon.2009.11.009

Nyström, M., and C. Folke. 2001. Spatial resilience in coral reefs. Ecosystems 4(5):406-417.

Olwig, K. R. 2008. The Jutland Cipher - Unlocking the Meaning and Power of a Contested Landscape Terrain. In: K. R. Olwig and M. Jones (Eds. ), Nordic Landscapes: Region and Belonging on the Northern Edge of Europe. University of Minnesota Press, Minneapolis, USA.

Olsson, P., and C. Folke. 2001. Local ecological knowledge and institutional dynamics for ecosystem management: a study of Lake RackenWatershed, Sweden. Ecosystems 4:85-104. http://dx.doi.org/10.1007/s100210000061

Oteros-Rozas, E., R. Ontillera-Sánchez, P. Sanosa, E. GómezBaggethun, V. Reyes-García, and J. A. González. 2013. Traditional ecological knowledge among transhumant pastoralists in Mediterranean Spain. Ecology and Society 18 (3): 33. http://dx.doi.org/10.5751/ES-05597-180333

Otero, I., M. Boada, and J. D. Tàbara. 2013. Social-ecological heritage and the conservation of Mediterranean landscapes under global change. A case study in Olzinelles (Catalonia). Land Use Policy 30:25-37. http://dx.doi.org/10.1016/j. landusepol.2012.02.005

Queiroz, C., 2013. Managing for biodiversity and ecosystem services in context of farmland abandonment. Doctoral thesis in Sustainability Science, Stockholm Resilience Centre, Stockholm University, Sweden.

Patel, R. 2008. Stuffed and Starved: Markets, Power and the Hidden Battle for the World Food System. Portobello Books, London, UK.

Pelletier, N., N. Arsenault, P. Tyedmers. 2008. Scenario modeling potential eco-efficiency gains from a transition to organic agriculture: life cycle perspectives on Canadian canola, corn, soy, and wheat production. Environmental Management 42(6):989-1001. http://dx.doi.org/10.1007/ $\underline{\mathrm{s} 00267-008-9155-\mathrm{X}}$

Perfecto, I., and J. Vandermeer. 2010. The agroecological matrix as alternative to the land sparing/agriculture intensification model. Proceedings of the Nional Academy of Science 107(13):5786-5791 http://dx.doi.org/10.1073/ pnas.0905455107

Perrings, C., S. F. Naeem, and F. Ahrestani, et al. 2010. Ecosystem Services for 2020. Science 15:323-324. http://dx. doi.org/10.1126/science.1196431

Petrini, C. 2007. Slow Food Nation: A Blueprint for Changing the Way We Eat. Rizzoli International Publications, NY., USA.
Phalan, B., M. Onial, A. Balmford, and R. E. Green. 2011. Reconciling Food production and Biodiversity conservation: Land sharing and land sparing compared. Science 333:1289-2191. http://dx.doi.org/10.1126/science.1208742

Polyani, M. 1966. The Tacit Dimension. London, Routledge, U. K. http://dx.doi.org/10.1016/B978-0-7506-9718-7.50010$\underline{X}$

Pretty, J. N., A. D. Noble, D. Bossio, J. Dixon, , R. E. Hinex F. W. T. Penning de Vries, and J. I. L. Morison. 2006. Resource-conserving agriculture increases yields in developing countries. Environmental Science and Technology 40(4):1114-1119. http://dx.doi.org/10.1021/es051670d

Reyes-García, V., V. Vadez, T. Huanca, W. R. Leonard, and T. McDade. 2007. Economic development and local ecological knowledge: a deadlock? Data from a native Amazonian society. Human Ecology 35:371-377. http://dx. doi.org/10.1007/s10745-006-9069-2

Reyes-García, V., M. Guèze, A. C. Luz, J. Paneque-Gálvez, M. J. Macía, M. Orta-Martínez, J. Pino, and X. RubioCampillo. 2013. Evidence of traditional knowledge loss among a contemporary indigenous society. Evolution and Human Behavior 34:249-257. http://dx.doi.org/10.1016/j. evolhumbehav.2013.03.002

Rindos, D. 1980. Symbiosis, instability, and the origins and spread of agriculture: A new model. Current Anthropology 21:751-772. http://dx.doi.org/10.1086/202569

Rindos, D. 1984. The Origins of Agriculture: An Evolutionary Perspective. Academic Press, Orland, FL., USA.

Rindos, D. 1986. The Genetics of Cultural Anthropology: Toward a Genetic Model for the Origin of the Capacity for Culture. Journal of Anthropological Archaeology 5:1-38.

Rockström, J., W. Steffen, K. Noone, et al. 2009. Planetary boundaries: exploring the safe operating space for humanity. Ecology and Society 14(2):32. [online] URL: http://www. ecologyandsociety. org/vol14/iss2/art32/

Rosset, P. M. 1999. The Multiple Functions and Benefits of Small Farm Agriculture in the Context of Global Trade Negotiations. Policy Brief, No 4, Food First, the Institute For Food and Development Policy. http://dx.doi.org/10.1057/ palgrave.development. 1110149

Ruiz-Mallén, I. and E. Corbera. 2013. Community-based conservation and traditional ecological knowledge: implications for social-ecological resilience. Ecology and Society 18(4):12. http://dx.doi.org/10.5751/ES-05867-180412

Rulli, C. M., A. Saviori, and P. Ddorico. 2013. Global Land and Water Grabbing. Proceedings of the National Academy of Science 110(3):892-897. http://dx.doi.org/10.1073/pnas.1213163110 
Scarborough , V. L. 2008. "Rate and Process of Societal Change in Semitropical Settings: The Ancient Maya and the Living Balinese. " Quaternary International 184:24-40.

Scheffer, M., and F. R. Westley. 2007. The evolutionary basis of rigidity: locks in cells, minds, and society. Ecology and Society 12(2):36. [online] URL: http://www. ecologyandsociety. org/vol12/iss2/art36/

Scott, J. C. 1998. Seeing Like a State: How Certain Schemes to Improve the Human Condition have Failed. Yale University Press, New Haven, CT, USA.

Sen, A. 1994. Population: delusion and reality. New York Review of Books 41(15): 62-71.

Sensiper, L. D. S. 1998. The role of tacit knowledge in group innovation. California Management Review 40: 112-132.

Siebert, C. 2011. Food Ark. National Geographic http://ngm. nationalgeographic.com/2011/07/food-ark/siebert-text/1

Steffen, W., Å. Persson, and L. Deutsch, et al. 2011. The Anthropocene: from global change to planetary stewardship. Ambio 40:739-761 http://dx.doi.org/10.1007/s13280-011-0185$\underline{\mathrm{X}}$

Steffen, W., P. J. Crutzen, and J. R. McNeill. 2007. The Anthropocene: Are humans now overwhelming the great forces of nature. Ambio 36(8):614-621. http://dx.doi. org/10.1579/0044-7447(2007)36[614:TAAHNO|2.0.CO;2

Steel, C. 2010. Hungry City-How Food Shapes Our Lives. Vintage Books, London, UK.

Steffan-Dewenter, I., S. G. Potts, and L. Packer. 2005. Pollinator diversity and crop pollination services are at risk. Trends in Ecological Evolution 20:651-652. http://dx.doi. org/10.1016/j.tree.2005.09.004

Steinberg, M. K. 2001. Valuing diversity: The role of "seedsavers" in in situ crop plant conservation. Culture and Agriculture 23(3):5. http://dx.doi.org/10.1525/cag.2001.23.3.41

Strumsky, D., J. Lobo, and J. A. Tainter. 2010. Complexity and the productivity of Innovation. Systems Research and Behavioral Science 27:496-509. http://dx.doi.org/10.1002/ $\underline{\text { sres. } 1057}$

Svedin, U. 2012. Global Conditions for the Future of Agriculture in 'anthropochene. In L. Turbiana, and R. K. Pachauri, editors. Towards Agricultural Change? A Planet For Life 2012-Sustainable development in action. French Development Agency, Institute of Sustainable Development and International relations the Energy and Resources Institute. Paris and New Dehli, Paris, France.

Takeuchi, K., R. D. Brown, I. Washitani, A. Tsunekawa, and M. Yokohari, editors. 2003. Satoyama: The Traditional Rural Landscape of Japan. Springer-Verlag, Tokyo, Japan.
Tallis, J. H. 1991. Plant community history. Chapman and Hall, London, U. K.

Tengö, M., K. Johansson, F. Rakotondrasoa, J. Lundberg, JA. Andriamaherilala, J-A. Rakotoarisoa, and T. Elmqvist. 2007. Taboos and forest governance: informal protection of hot spot dry forest in southern Madagascar. Ambio 36:683-691. http://dx.doi.org/10.1579/0044-7447(2007)36 [683:TAFGIP]2.0.CO;2

Tengö, M., and K. Belfrage. 2004. Local management practices for dealing with change and uncertainty: a crossscale comparison of cases in Sweden and Tanzania. Ecology and Society 9(3): 4. [online] URL: http://www. ecologyandsociety.org/vol9/iss3/art4/

Tribsch, A. and P. Schönswetter. 2003. Patterns of endemism and comparative phylogeography confirm paleoenvironmental evidence for Pleistocene refugia in the eastern alps. Taxon 52 (3):477-497. http://dx.doi.org/10.2307/3647447

Tscharntke, T., A-M. Klein, A. Kruess, I. Steffan-Dewenter, and C. Thies. 2005. Landscape perspectives on agricultural intensification and biodiversity-ecosystem service management. Ecology Letters 8(8):857-874. http://dx.doi.org/10.1111/ j.1461-0248.2005.00782.X

Turner, N., and P. R. Spalding. 2013. "We might go back to this"; drawing on the past to meet the future in northwestern North American indigenous communities. Ecology and Society 18(4): 29. http://dx.doi.org/10.5751/ES-05981-180429

Watts, M., and H. G. Bohle. 1993. "The space of vulnerability: the causal structure of hunger and famine". Progress in Human Geography 17(1):43-67. http://dx.doi.org/10.1177/0309132$\underline{59301700103}$

Wenger, E. 1998. Community of Practice: Learning, Meaning and Identity. Cambridge University Press, Cambridge, UK. http://dx.doi.org/10.1017/CBO9780511803932

Widgren, M. 2007. Pre-Colonial Landesque Capital: A Global Perspective. In A. Hornborg, J. Martinez-Alier, and J. R. Mcneill, editors. Rethinking Environmental History: WorldSystem History and Global Environmental Change, pp. 61-77. AltaMira Press, Walnut Creek, USA.

Vitousek, P. M., H. A. Mooney, J. Lubchenco, and J. M. Melillo. 1997. Human domination of Earth's ecosystems. Science 277:494-99. http://dx.doi.org/10.1126/science.277.5325.494 